Jurnal ABDIMAS INDEPENDEN

Vol. 1, No. 1, Mei 2020

\title{
PENGUATAN USAHA TAHU DAN TEMPE KEKALIK MELALUI PELATIHAN MENGHITUNG HARGA POKOK PRODUKSI DENGAN PENDEKATAN FULL COSTING
}

\author{
Lukman Effendy \\ Fakultas Ekonomi dan Bisnis Universitas Mataram \\ lukman.effendy@unram.ac.id \\ Isnawati \\ Fakultas Ekonomi dan Bisnis Universitas Mataram \\ isnawati.isna@unram.ac.id \\ Eni Indriani \\ Fakultas Ekonomi dan Bisnis Universitas Mataram \\ eni.indriani@unram.ac.id
}

\begin{abstract}
Ringkasan
Masalah pokok yang sering terjadi dari para pengusaha industri tahu tempe adalah meningkatnya harga kacang kedelai dalam beberapa bulan ini. Kelangkaan kedelai impor dari Thailand yang merupakan kedelai dengan kualitas terbaik dan yang digunakan oleh usaha tahu tempe Pak Satriawan inilah yang menyebabkan harga kacang kedelai meningkat drastis. Selama ini, perhitungan biaya produksi yang dilakukan oleh perusahaan hanya berdasarkan perkiraan saja. Perusahaan hanya menghitung biaya produksi berdasarkan bahan baku saja tanpa menghitung biaya seperti penyusutan, gaji karyawan, dan biaya overhead pabrik. Hal ini dapat mempengaruhi keuntungan yang didapat oleh perusahaan dan dapat membuat perusahaan mengalami kerugian. Solusi yang ditawarkan untuk masalah perhitungan harga pokok produksi yang dihadapi para pengusaha tahu dan tempe milik Pak Satriawan di Kekalik, dengan cara memberikan pelatihan cara menghitung harga pokok produksi yang sesuai menggunakan pendekatan Full Costing. Harapannya dari kegiatan PKM ini,
\end{abstract}


Pak Satriawan benar-benar menentukan harga jual berdasarkan harga pokok produksi yang sudah dihitung sebelumnya. Kegiatan Pengabdian ini berjalan dengan lancar dan telah berhasil memberikan pemahaman kepada Bapak Satriawan bahwa perhitungan harga pokok produksi yang diterapkan selama ini masih keliru, karena perhitungannya tidak berdasar pada metode atau konsep Full Costing atau Variabel Costing. Dari kegiatan pengabdian ini memberikan kesimpulan bahwa terdapat selisih harga pokok menurut perhitungan Bapak Satriawan dengan perhitungan Metode Full Costing sebesar Rp. 338 (Rp.20.390 - Rp.20.052) percetak dan Rp.16.900 (Rp.338 x 50 cetak) per hari.

Kata Kunci : Harga Pokok Produksi; Full Costing; Usaha Kecil dan Menengah. 
Jurnal ABDIMAS INDEPENDEN

Vol. 1, No. 1, Mei 2020

\section{PENDAHULUAN}

\section{Latar Belakang}

Menurut UU no. 5 Tahun 1984, industri adalah kegiatan ekonomi mengolah bahan mentah, barang baku, barang setengah jadi dan atau barang jadi menjadi barang dengan nilai yang lebih tinggi penggunaanya, termasuk kegiatan rancang bangun dan perekayasaan industri. Bahan-bahan industri diambil secara langsung maupun tidak langsung, kemudian diolah, sehingga menghasilkan barang yang bernilai lebih dan memiliki nilai guna bagi masyarakat. Kegiatan proses produksi dalam industri itu disebut dengan perindustrian. Salah satu contohnya adalah industry tahu dan tempe.

Industri tahu dan tempe merupakan salah satu industri kecil-menengah yang mampu menyerap sejumlah tenaga kerja. Peluang Industri tahu dan tempe sangat baik mengingat pertumbuhan permintaan terhadap produk tempe setelah Tahun 1998 diperkirakan mencapai 4 persen per tahun(Solahudin, 1998). Menurut Ambarwati (1994), para pengusaha tahu dan tempe pada umumnya dikelola dalam bentuk industri rumah tangga (home industri), sehingga perkembangannya selalu dihadapkan dengan permasalahan yang menyangkut bahan baku yaitu kedelai, ketersediaan dan kualitas faktor produksi, tingkat keuntungan, pemasaran serta permodalan. Pendapatan para pengrajin tahu dan tempe sangat tergantung dari penjualan dan biaya-biaya produksi yang dikeluarkan. Tidak berbeda dengan usaha-usaha lainnya, home industri tahu dan tempe juga akan bertahan hidup serta berkembang apabila mampu mengelola biaya secara efektif dan efisien, demi meraih laba maksimal. Apabila sebuah perusahaan tidak dapat mengelola biaya secara baik, maka laba atau keuntungan pada perusahaan tersebut akan sulit dicapai, bahkan dapat mengakibatkan kerugian.

Kenaikan harga bahan bakar minyak (BBM) menjadikan harga kedelai dan harga bahan-bahan seperti kemasan baik plastik maupun daun, ragi dan minyak tanah menjadi naik. Kenaikan harga barang-barang tersebut telah menyebabkan 
biaya produksi yang dikeluarkan juga semakin besar. Kondisi ini sangat dirasakan oleh para pengrajin tempe yang mempunyai modal pas-pasan sehingga jalan keluar yang terbaik untuk bertahan dalam industri tempe adalah dengan mengurangi volume produksi.

Salah satu masalah lain dari para pengusaha industri tahu tempe adalah meningkatnya harga kacang kedelai dalam beberapa bulan ini. Kelangkaan kedelai impor dari Thailand yang merupakan kedelai dengan kualitas terbaik dan yang digunakan oleh usaha tahu tempe Bapak Satriawan inilah yang menyebabkan harga kacang kedelai meningkat drastis. Selama ini, perhitungan biaya produksi yang dilakukan oleh perusahaan hanya berdasarkan perkiraan saja. Perusahaan hanya menghitung biaya produksi berdasarkan bahan baku saja tanpa menghitung biaya seperti penyusutan, gaji karyawan, dan biaya overhead pabrik. Hal ini dapat mempengaruhi keuntungan yang didapat oleh perusahaan dan dapat membuat perusahaan mengalami kerugian.

Oleh sebab itu perusahaan harus melakukan perhitungan harga pokok produksi secara tepat. Agar produksi yang dihasilkan dapat dijual dengan harga yang bersaing dan dengan kualitas yang bersaing juga. Selain itu agar dapat mengikuti perubahan dari harga kacang yang tidak stabil. Begitu juga dengan home industri tahu tempe Pak Satriawan Kekalik Mataram.

\section{Permasalahan}

Masalah pokok yang sering terjadi dari para pengusaha industri tahu tempe adalah meningkatnya harga kacang kedelai dalam beberapa bulan ini. Kelangkaan kedelai impor dari Thailand yang merupakan kedelai dengan kualitas terbaik dan yang digunakan oleh usaha tahu tempe Pak Satriawan inilah yang menyebabkan harga kacang kedelai meningkat drastis. Selama ini, perhitungan biaya produksi yang dilakukan oleh perusahaan hanya berdasarkan perkiraan saja. Perusahaan hanya menghitung biaya produksi berdasarkan bahan baku saja tanpa menghitung biaya seperti penyusutan, gaji karyawan, dan biaya overhead 


\section{Jurnal ABDIMAS INDEPENDEN}

Vol. 1, No. 1, Mei 2020

pabrik. Hal ini dapat mempengaruhi keuntungan yang didapat oleh perusahaan dan dapat membuat perusahaan mengalami kerugian.

\section{Tujuan}

Tujuan dilakukannya kegiatan pengabdian pada masyarakat ini adalah untuk melatih pemilik usaha untuk bisa menghitung biaya produksi tahu dan tempenya berdasarkan metode atau konsep perhitungan yang lebih relevan dalam perusahaan manufaktur.

\section{Manfaat}

Kegiatan pengabdian pada Masyarakat ini diharapkan dapat meningkatkan kemampuan Sumber Daya Manusia (SDM) yaitu pemilik usahan dalam menghitunga harga pokok produksinya berdasarkan metode perhitungan yang relevan dengan proses produksi perusahaan manufaktur.

\section{SOLUSI DAN TARGET LUARAN}

\section{Solusi}

Berdasarkan uraian pada latar belakang dan permasalahan yang dijelaskan di atas, maka kegiatan pengabdian kepada masyarakat ini menawarkan solusi untuk masalah perhitungan harga pokok produksi yang dihadapi para pengusaha tahu dan tempe milik Pak Satriawan di Kekalik, dengan cara memberikan pelatihan cara menghitung harga pokok produksi yang sesuai menggunakan pendekatan Full Costing. Harapannya dari kegiatan PKM ini, Pak Satriawan benar-benar menentukan harga jual berdasarkan harga pokok produksi yang sudah dihitung sebelumnya. Hasil dari kegiatan pengabdian ini akan dipublikasikan pada salah satu Jurnal Pengabdian Kepada Masyarakat.

\section{Target Luaran}

Publikasi ini menjadi target luaran dari kegiatan PKM ini. 


\section{METODE PELAKSANAAN}

Pendekatan/metode pelaksanaan kegiatan pengabdian ini dilakukan dengan metode workshop / pelatihan, yaitu pelatihan menghitung harga pokok produksi dengan pendekatan Full Costing.

\section{HASIL DAN PEMBAHASAN}

\section{Gambaran Umum Usaha Tahu Tempe Bapak Satriawan}

Kegiatan Pengabdian pada Masyarakat ini direncanakn akan dilaksanakan di Kota Mataram dengan mengundang pengurus koperasi yang ada di Kota Mataram. Pemilihan lokasi di Kota Mataram mengingat koperasi-koperasi yang berukuran besar dan yang masih aktif sebagian besar berada di Kota Mataram.

\section{Gambaran Umun IImu Pengetahuan dan Tenologi (Iptek) Harga Pokok Produksi}

Menurut Firmansyah (2014:57) menyatakan bahwa Harga Pokok Produksi adalah penjumlahan seluruh pengorbanan sumber ekonomi yang digunakan dalam pengolahan bahan baku menjadi produk jadi. Suatu perusahaan perlu menentukan harga pokok produksi yang dihasilkan karena harga pokok merupakan salah satu factor yang ikut mempengaruhi harga jual dasar dan penentuan kebijakan-kebijakan yang berhubungan dengan pengolahan perusahaan.

\section{Tujuan Perhitungan Harga Pokok Produksi}

Adapun tujuan dari perhitungan harga pokok produksi adalah sebagai berikut:

a. Sebagai salah satu factor yang harus dipertimbangkan dalam penentuan harga jual produk didasarkan pada biaya produksi ditambahn biaya lain yang telah dikeluarkan dan laba yang diinginkan

b. Sebagai salah satu factor yang harus dipertimbangkan dalam penentuan biaya produk untuk produk baru dan pesanan khusus 


\section{Jurnal ABDIMAS INDEPENDEN}

Vol. 1, No. 1, Mei 2020

c. Untuk penentu kebijakan penjualan

\section{Unsur-Unsur Biaya Penentu Harga Pokok Produksi}

Menurut Witjaksono (2006), biaya-biaya dalam penentuan harga pokok produksi terdiri dari tiga (3) unsur yaitu:

a. Biaya Bahan Baku (Direct Materials)

b. Biaya Tenaga Kerja Langsung (Direct Labour)

c. Biaya Overhead Pabrik (BOP)

\section{Pendekatan Penentuan Harga Pokok Produksi}

Menurut Mulyadi (2009:18), dalam memperhitungkan unsur-unsur biaya ke dalam harga pokok produksi, terdapat dua (2) pendekatan yaitu:

1. Full Costing, merupakan metode penentuan harga pokok produksi yang memperhitungkan semua unsur biaya produksi ke dalam harga pokok produksi, yang teridir dari biaya bahan baku, biaya tenaga kerja langsung dan biaya overhead pabrik, baik yang berperilaku variable maupun yang berperilaku tetap.

2. Variabel Costing, yaitu metode penentuan harga pokok produksi yang hanya membebankan biaya-biaya produksi saja kedalam harga pokok produk, yang terdiri dari biaya bahan baku, biaya tenaga kerja langsung serta biaya overhead pabrik yang berperilaku variable saja.

\section{Proses Produksi Tahu Dan Tempe}

\section{A. Sekilas tentang Tahu dan Proses Produksinya}




\section{Gambar. 1: Produk Selesai Tahu}

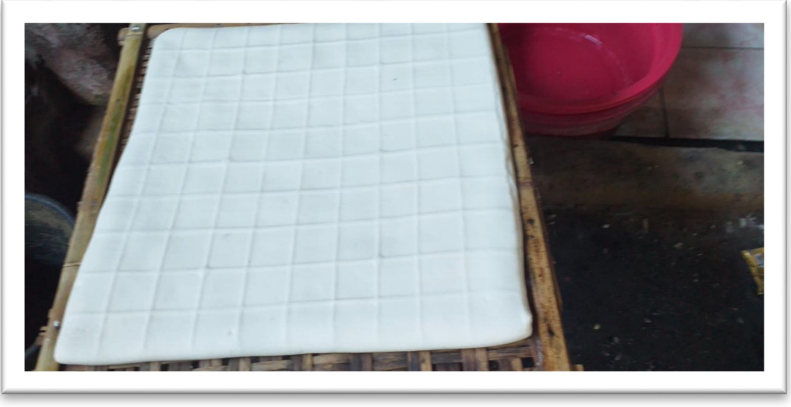

Sumber : Usaha Tahu Tempe Bapak Satriawan Kekalik

Tahu adalah makanan yang dibuat dari kacang kedelai yang difermentasi dan diambil sarinya. Berbeda dari tempe yang asli dari Indonesia, Tahu berasal dari Cina seperti halnya Kecap; tauco; Bakpau; dan Bakso. Tahu adalah serapan dari Bahasa Hokkian (Tauhu) yang secara harfiah berarti "kedelai yang difermentasi".

Berikut adalah proses pembuatan Tahu secara garis besarnya:

- Pilih kedelai yang bersih dan besar ukurannya, kemudian cuci sampai bersih.

- Rendam kedelai dalam air bersih selama 8 jam, usahakan seluruh kedelai tenggelam. Dalam proses perendaman ini kedelai akan mengembang.

- Bersihkan kembali kedelai dengan cara dicuci berkali-kali. Usahakan kedelai ini sebersih mungkin untuk menghindari kedelai cepat masam.

- Hancurkan kedelai dengan cara ditumbuk (digiling) dan secara perlahan tambahkan air sedikit demi sedikit sehingga kedelainya berbentuk bubur.

- Masak bubur kedelai dengan hati-hati pada suhu 70 - 80 derajat (biasanya ditandai dengan gelembung kecil yang muncul pada kedelai masak). Ingat untuk menjaga agar kedelai jangan sampai mengental.

- Saring bubur kedalai tersebut Bersama batu Tahu atau asam cuka sambal diaduk secara perlahan. Proses ini akan menghasilkan endapan Tahu (gumpalan). 
Jurnal ABDIMAS INDEPENDEN

Vol. 1, No. 1, Mei 2020

- Endapan itu kemudian siap untuk dipress dan dicetak sesuai ukuran dan keinginan anda.

- Keluarkan Tahu dari cetakan, potong sesuai selera dan siap dikonsumsi.

\section{B. Sekilas Tentang Tempe dan Proses Produksi Tempe}

Tempe adalah salah satu jenis makanan yang banyak difavoritkan oleh masyarakat Indonesia. Mengapa? Selain rasanya yang gurih, tempe ternyata mengandung banyak protein nabati yang sangat baik untuk metabolism tubuh. Apalagi dewasa ini bermunculan ide masak yang terbuat dari tempe ini, salah satunya adalah steak yang pasti tak kalah enaknya dari steak daging.

Gambar 2. Produk Selesai Tempe

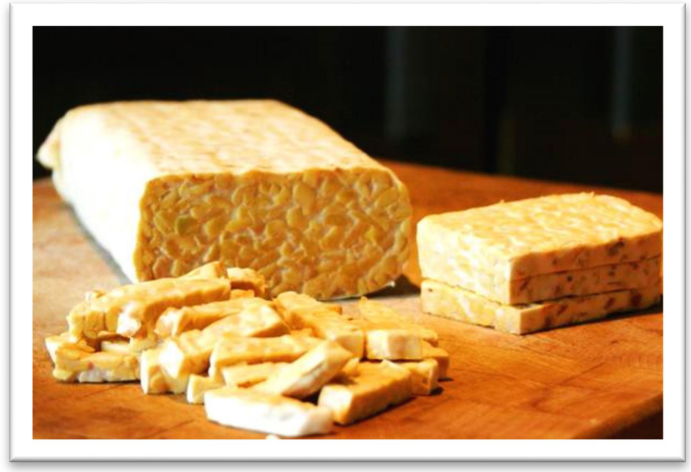

Sumber: Wikipedia.org

Berikut adalah langkah-langkah mebuat Tempe secara garis besar:

- Cuci versih kedelai

- Rendamlah kedelai kurang lebih selama 13 - 18 jam, jika sudah lunak, lalu cuci bersih kedelai sambil biji kedelai dipisahkan dari kulitnya.

- Rebus biji kedelai sampai mendidih. Tiriskan pada tampah kemudian didinginkan bila perlu menggunakan kipas angina hingga tidak terlalu panas. 
- Masukkan ragi tempe secara merata ke tempe yang sudah mulai dingin, aduk rata.

- Masukkan kedelai yang sudah bercampur ragi ke dalam cetakan Tempe yang sudah dilapisi Kantong plastic atau Daun Pisang.

- Biarkan di dalam suhu kamar selama kurang lebih 48 jam untuk proses fermentasi untuk siap dikonsumsi.

\section{HASIL DAN PEMBAHASAN}

Hasil

Usaha pembuatan Tahu Tempe Bapak Satriawan sudah ada sekitar 32 tahun yang lalu, yaitu langsung merambah pada usaha pembuatan 2 jenis produk yaitu tahu dan Tempe. Namun belakangan sejak tahun 2009, Bapak Satriawan sudah tidak memproduksi lagi Tempe. Beberapa alasan diberhentikannya pembuatan produk Tempe antara lain: proses pembuatan yang membutuhkan sekitar 4 hari, membuat para pengusaha yang memiliki modal terbatas seperti Bapak Satriawan menganggap produk Tempe ini kurang menguntungkan dalam perputaran uangnya. Sehingga jika keuntungan yang diperoleh pada saat penjualan dibagi dengan lamanya proses produksi, maka akan memberikan angka rata-rata keuntungan per harinya lebih kecil jika dibandingkan dengan keuntungan produk Tahu yang memiliki masa produksi hanya 1 hari. Namun demikian, dalam laporan kegiatan pengabdian ini akan tetap diuraikan perhitungan harga pokok produksi Tempe dengan pendekatan Full Costing berdasarkan data yang berhasil dikumpulkan dari pengalaman Bapak Satriwan pada saat masih membuat produk Tempe.

Bapak Satriawan tidak menggunakan pendekatan apapun untuk menghitung harga pokok produkyang sesuai dengan kaidah akuntansi biaya dan tidak mempertimbangkan biaya produksi secara detail. Maka untuk menghindari terjadinya kesalahan dalam perhitungan biaya produksi dan agar menghasilkan biaya yang efisien diperlukan suatu metode yang baik. Adapun metode yang 


\section{Jurnal ABDIMAS INDEPENDEN}

Vol. 1, No. 1, Mei 2020

dapat digunakan dalam perhitungan biaya produksi tersebut adalah metode full costing dan variable costing. Tentulah metode-metode tersebut sama sekali belum menyentuh para pengusaha seperti usaha Tahu Tempe Bapak Satriawan, maka metode-metode perhitungan Harga Pokok Produksi tersebut diperkenalkan melalui kegiatan Pengabdian kepada Masyarakat, khususnya metode Full Costing. Yaitu metode yang dianggap cocok dengan pola produksi Bapak Satriawan

Kegiatan pengabdian terlaksana pada hari Kamis, 8 Agustus 2019 yang dimulai dari Pukul 09.00 wita sampai dengan selesai. Kegiatan pengabdian dilaksanakan dengan menggunakan metode diskusi dua arah, dan berikut adalah rincian kegiatan pengabdian yang dilaksanakan:

- Kegiatan diskusi awal antara tim pengabdian dengan Bapak Satriawan; yaitu memberikan Bapak Satriawan kesempatan untuk menjelaskan tentang proses pembuatan Tahu Tempe yang selama ini dilakukan. Kegiatan ini bertujuan untuk menganalisa biaya-biaya produksi yang muncul dari proses pembuatan produk Tahu Tempe. Dan berikut data produksi Tahu berdasarkan penjelasan Bapak Satriawan.

Tabel 1. Data Harga Pokok Produksi Tahu Per Hari

\begin{tabular}{|c|c|c|c|c|c|}
\hline No & Jenis Biaya & Unit & $\begin{array}{l}\text { Harga } \\
\text { (Rp) }\end{array}$ & $\begin{array}{l}\text { Jumlah } \\
\text { (Rp) }\end{array}$ & $\begin{array}{l}\text { TOTAL } \\
\text { (Rp) }\end{array}$ \\
\hline 1 & $\begin{array}{l}\text { Biaya Bahan Baku (Kacang Kedelai) } \\
\text { Jumlah Biaya Bahan Baku }\end{array}$ & $100 \mathrm{~kg}$ & 7,000 & 700,000 & 700,000 \\
\hline 2 & $\begin{array}{l}\text { Biaya Tenaga Kerja Langsung: } \\
\text { * Proses Produksi } \\
\text { * Biaya makan } \\
\text { * Biaya Rokok } \\
\text { Jumlah Biaya Tenaga kerja Langsung }\end{array}$ & $\begin{array}{l}50 \text { cetak } \\
2 \text { orang } \\
2 \text { orang }\end{array}$ & $\begin{array}{l}2,500 \\
5,000 \\
18,000\end{array}$ & $\begin{array}{l}125,000 \\
10,000 \\
36,000\end{array}$ & \\
\hline
\end{tabular}




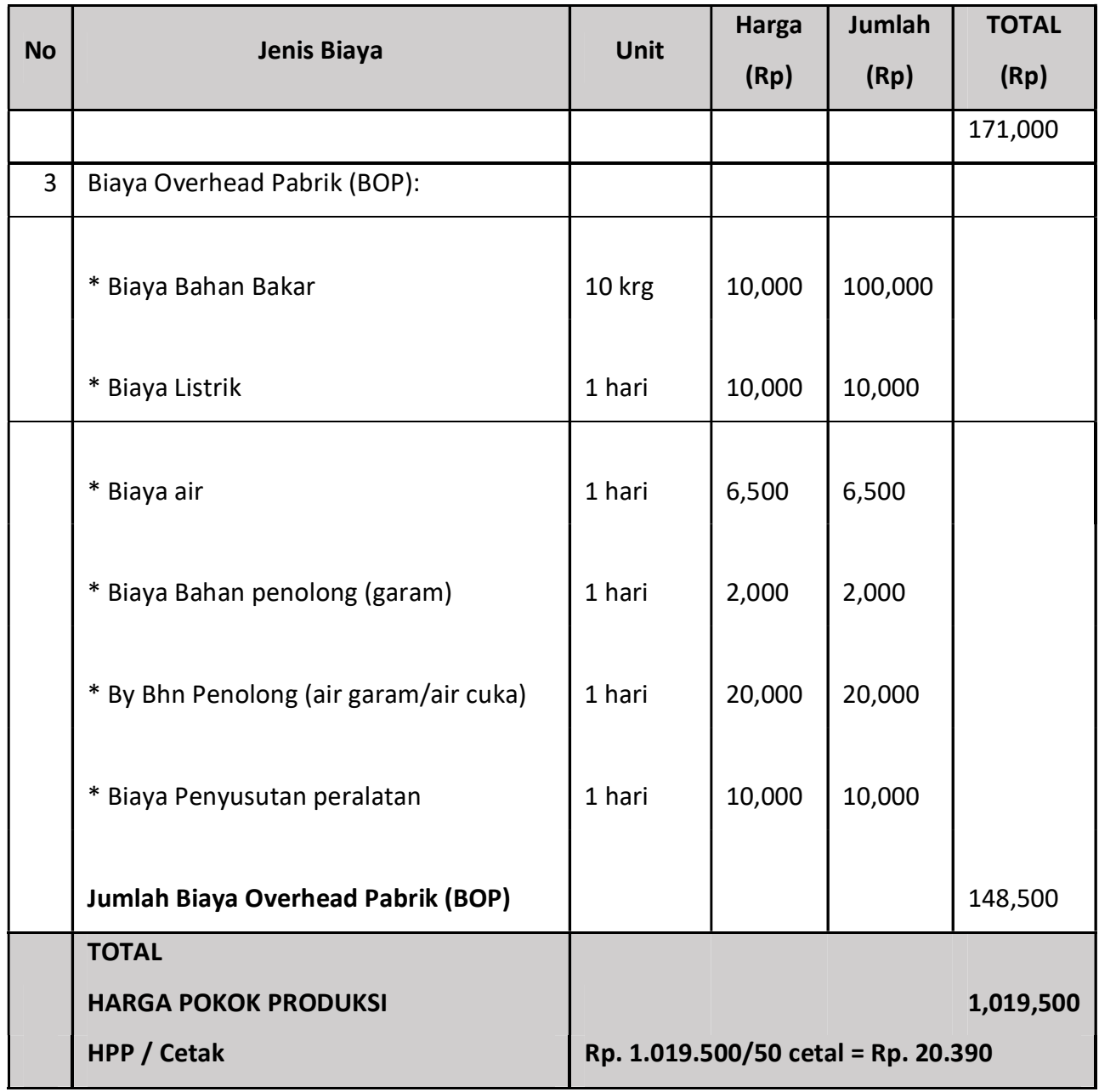

Sumber: Data primer (diolah)

Keterangan:

- Biaya Listrik Per Bulan rata-rata Rp. 600.000. oleh Bapak Satriawan membebankan biaya listrik ini ke dalam dua fungsi, fungsi produksi dan fungsi rumah tangga. Sehingga biaya listrik untuk bagian produksi dibebankan sebesar Rp.300.000 per bulan. Sehingga pembebanan biaya listrik per hari untuk bagian produksi sebesar Rp. 300.000 / 30 hari $=$ Rp. 10.000 per hari.

- Biaya air (PDAM) juga dibebankan ke dama fungsi produksi dan fungsi rumah tangga. Untuk itu beban air yang dialokasikan ke pabrik sebanyak $50 \%$ dari rata-rata pengeluaran air setiap bulannya. Maka 
Jurnal ABDIMAS INDEPENDEN

Vol. 1, No. 1, Mei 2020

perhitungan alokasi beban air untuk bagian produksi sebesar $(50 \% \mathrm{x}$ Rp $400.000=$ Rp 200.000 per bulan ), sehingga beban air per hari sebesar Rp. 6.500 (pembulatan ke bawah; Rp.200.000/30 hari).

- Peralatan maupun asset tetap yang dimiliki tidak menggunakan metode apapun dalam menghitung penyusutan atau penurunan nilainya dari waktu ke waktu. Bapak Satriawan hanya menggunakan perkiraan saja dalam mengakui penyusutan peralatan. Bahkan ada salah satu peralatan yang dimiliki tidak disusutkan sama sekali, dikarenakan peralatan tersebut diperoleh melalui hibah Pemerintah. Maka dari itu diperoleh angka penyusutan peralatan sebesar Rp. 10.000 / hari berdasarkan perkiraan Bapak Satriawan.

- Proses produksi Tahu Bapak Satriawan perharinya menghasilkan sekitar 50 cetak dengan harga jual Rp. 30.000/ cetak. Harga jula tersebut adalah harga jual dari Bapak Satriawan ke pihak ke dua (diistilahkan sebagai "Penendak").

- Proses produksi dimulai dari jam 06.00 wita dan selesai sekitar jam 16.00 wita. Hasil produksi hari itu langsung dipasarkan pada hari itu juga di pasar-pasar tradisional seperti "Pasar Kebon Rowek" dan Pasar "Bertasi". Dan dari proses pembuatan Tahu tersebut, terdapat ampas (limbah) Tahu yang ternyata bisa dimanfaatkan sebagai bahan baku pembuatan kerupuk Tahu. Sehingga limbah (ampas) pembuatan Tahu tersebut bisa dijual dengan harga Rp. 2.500 per cetak.

- Melakukan perhitungan Laba/Rugi per hari untuk penjualan produk Tahu Bapak Satriawan, seperti yang terlihat pada tabel di bawah ini:

Tabel 2: Laba Rugi/ Hari dari Penjualan Tahu

\begin{tabular}{|l|l|}
\hline \multicolumn{1}{|c|}{ Keterangan } & \multicolumn{1}{c|}{ Rupiah } \\
\hline Penjualan Tahu 50 cetak @Rp. 30.000 & Rp. 1.500.000 \\
\hline Harga Pokok Penjualan & (Rp. 1.019.500) \\
\hline Laba Kotor & Rp. 480.500 \\
\hline
\end{tabular}




\begin{tabular}{|l|c|}
\hline \multicolumn{1}{|c|}{ Keterangan } & \multicolumn{1}{c|}{ Rupiah } \\
\hline $\begin{array}{l}\text { Penjualan ampas (limbah) Tahu 5 } \\
50 \text { cetak @ Rp.2.500 }\end{array}$ & Rp. 125.000 \\
\hline Laba Bersih / Hari & Rp. $\mathbf{6 0 5 . 5 0 0}$ \\
\hline
\end{tabular}

Sumber: Data Primer (diolah)

- Diskusi lanjutan, dengan memberikan kesempatan kepada tim pengabdian untuk menjelaskan ke Bapak Satriawan tentang metode perhitungan harga pokok produksi dengan menggunakan pendekatan Full Costing. Untuk selanjutnya tim mencoba menghitungkan harga pokok produksi produk Tahu yang dihasilkan oleh Bapak Satriawan. Namun terlebih dahulu tim mencoba menghitung alokasi Biaya Overhead Pabrik (BOP) berdasarkan aktivitas. Dan berikut adalah alokasi BOP untuk produksi Tahu usaha Bapak Satriawan:

- Beban Listrik

Berdasarkan informasi yang diperoleh dari penjelasan Bapak Satriawan, bahwa penggunaan listrik di bagian pabrik hanya pada saat penggilingan kacang kedelai dengan menggunakan mesin penggilingan. Selebihnya listrik digunakan untuk kebutuhan rumah tangga Bapak Satriawan. Sehingga tim memperhitungkan alokasi yang sesuai untuk beban listrik ke pabrik hanya sebesar $10 \%$. Oleh karena itu beban listrik per hari untuk pabrik dapat diperhitungkan sebagai berikut:

Beban Listrik rata-rata / bulan Rp. 600.000, maka alokasi ke bagian pabrik sebesar Rp. $10 \%$ x Rp. $600.000=$ Rp. 60.000 / bulan. Sehingga beban listrik bagian pabrik per harinya adalah Rp. $60.000 / 30$ hari $=$ Rp. 2.000

\section{- Beban Air}




\section{Jurnal ABDIMAS INDEPENDEN}

Vol. 1, No. 1, Mei 2020

Penggunaan air untuk bagian pabrik tidak berbeda jauh dengan penggunaan listrik, yaitu sebagian besar dipergunakan untuk keperluan rumah tangga Bapak Satriawan. Sedangkan penggunaan air di bagian pabrik hanya sebesar $30 \%$ dari keseluruhan penggunaan air yang ada. Oleh karena itu alokasi beban air untuk bagian pabrik dapat diperhitungakan sebagai berikut:

Beban air rata-rata per bulan sebesar Rp. 400.000, maka alokasi beban air per bulan untuk bagian pabrik adalah $(30 \% \times$ Rp. $400.000=$ Rp.120.000). dengan demikian beban air per hari untuk bagian pabrik adalah Rp. $120.000 / 30$ hari $=$ Rp.4.000

- Beban Penyusutan Aset Tetap

Berikut adalah aset tetap yang digunakan di bagian pabrik Bapak Satriawan:

Tabel 3: Peralatan Pembuatan Tahu

\begin{tabular}{|l|l|l|l|}
\hline No & Keterangan & Harga Perolehan & Masa Pakai \\
\hline 1 & Mesin penggiling & Rp. 3.500.000,- & 4 Tahun \\
\hline 2 & Tungku masak (panci) & Rp. 2.000 .000 & 7 Tahun \\
\hline 3 & Wadah plastic & Rp. 100.000 & 3 bulan \\
\hline 4 & Cetakan Tahu & Rp. 1.500 .000 & 10 Tahun \\
\hline 5 & Drum & Rp. 200.000 & 2 Tahun \\
\hline
\end{tabular}

Sumber: Data Primer (diolah)

\section{Keterangan Penyusutan:}

1. Penyusutan Mesin

Mesin penggiling yang dimiliki tersebut sudah dipakai selama empat (4) tahun lamanya. Umur ekonomis mesin ini menurut Analisa Bapak Satriawan adalah selama 6 Tahun. Maka besarnya penyusutan mesin dengan menggunakan metode garis lurus adalah sebagai berikut:

Penyusutan Mesin Per Tahun $=\frac{R p .3 .500 .000}{6 \text { Tahun }}$ 
$=\operatorname{Rp} .583 .000$

Penyusutan Mesin Per Hari = Rp. 583.000/360 = Rp. 1.620

2. Penyusutan Tungku Masak

Tungku masak sudah digunakan selama 7 Tahun. Berdasarkan Analisa dari Bapak Satriawan tungku tersebut masih berfungsi dengan baik sampai di Tahun ke 9 nantinya. Oleh karena itu besaran penyusutan Tungku masak sebagai berikut:

Penyusutan Tungku masak Per Tahun $=\frac{R p .2 .000 .000}{8 \text { Tahun }}$

$=$ Rp. 250.000

Penyusutan Tungku Masak per Hari = Rp. 250.000/360 hari

$=$ Rp.695

3. Penyusutan Wadah Plastik

Wadah plastic sudah dipakai 3 bulan lamanya. Biasanya wadah plastik bisa bertahan dengan masa pemakaian lebih dari 1 tahun jika tidak jatuh dan menyebabkan pecah. Namun seringkali masa pakai wadah plastik ini menjadi singkat dikarenakan pecah tersebut. Dan berdasarkan pengalaman Bapak Satriawan, wadah plastic akan diganti setelah 5 bulan pemakaian. Berdasarkan data tersebut, maka besar penyusutan Wadah Plastik dapat dihitung sebagai berikut:

Penyusutan wadah Plastik Per bulan $=\frac{R p .100 .000}{5 \text { bulan }}$

= Rp. 20.000

Penyusutan wadah plastic per hari sebesar $=$ Rp. $20.000 / 30$ hari

$=\operatorname{Rp} 667$

4. Penyusutan Cetakan Tahu

Cetakan Tahu sudah terpakai 10 tahun lamanya. Menurut informasi Bapak Satriwan, bahwa cetakan Tahu ini biasanya akan rusak setelah 5 tahun pemakaian jika tidak dibersihkan dengan 


\section{Jurnal ABDIMAS INDEPENDEN}

Vol. 1, No. 1, Mei 2020

rutin setiapkali selesai dipakai untuk mencetak Tahu. Dan cetakan milik Bapak Satriawan ini rutin dibersihkan, sehingga masa pemakaiannya bisa mencapai 10 tahun lamanya, bahkan diperkirakan masih bisa dipergunakan sampai dengan tahun ke 12 nantinya. Oleh karena itu besar penyusutan cetakan Tahu ini dapat dihitung sebagai berikut:

$\begin{aligned} \text { Penyusutan Cetakan Tahu Per Tahun } & =\frac{R p .1 .500 .000}{12 \text { Tahun }} \\ & =\mathrm{Rp} .125 .000\end{aligned}$

Penyusutan Cetakan Tahu Per Hari $=$ Rp. $125.000 / 360$ hari $=$ Rp.347

5. Penyusutan Drum

Drum ini digunakan sebagai tangki memasak adonan Tahu, dan sudah digunalan selama 2 tahun. Tangki Drum ini diperkirakan masih bisa terpakai sampai dengan 3 tahun lamanya. Maka penyusutan tangka Drum dapat dihitung sebagai berikut:

$$
\begin{aligned}
\text { Penyusutan Tangki Drum Per Tahun } & =\frac{R p .200 .000}{2 \text { Tahun }} \\
& =\text { Rp. } 100.000
\end{aligned}
$$

Penyusutan Tangki Drum per hari $=$ Rp. $100.000 / 360$ hari

$=$ Rp. 278

Berdasarkan perhitungan penyusutan setiap asset tetap yang digunakan untuk proses produksi Tahu Bapak Satriawan, maka berikut adalah total beban penyusutan asset tetap tersebut:

Tabel 4: Nilai Penyusutan Peralatan Pembuatan Tahu/Hari

\begin{tabular}{|l|l|l|}
\hline No & \multicolumn{1}{|c|}{ Keterangan } & Penyusutan/Hari \\
\hline 1 & Mesin Penggiling & Rp. 1.620 \\
\hline 2 & Tungku Masak & Rp 695 \\
\hline 3 & Wadah Plastik & Rp. 667 \\
\hline 4 & Cetajan Tahu & Rp. 347 \\
\hline
\end{tabular}




\begin{tabular}{|l|l|l|}
\hline No & \multicolumn{1}{|c|}{ Keterangan } & Penyusutan/Hari \\
\hline 5 & Tangki Drum & Rp. 278 \\
\hline & Jumlah & Rp. 3.607 \\
\hline
\end{tabular}

Sumber: Data Primer (diolah)

Dengan demikian Harga Pokok Produksi Produk Tahu Bapak

Satriawan dapat dihitung sebagai berikut:

Tabel 5 : Harga Pokok Produksi Berdasarkan Metode Full Costing

\begin{tabular}{|c|c|c|c|c|c|}
\hline No & Jenis Biaya & Unit & $\begin{array}{l}\text { Harga } \\
(\mathbf{R p})\end{array}$ & $\begin{array}{l}\text { Jumlah } \\
\text { (Rp) }\end{array}$ & $\begin{array}{l}\text { TOTAL } \\
\text { (Rp) }\end{array}$ \\
\hline 1 & $\begin{array}{l}\text { Biaya Bahan Baku (Kacang Kedelai) } \\
\text { Jumlah Biaya Bahan Baku }\end{array}$ & $100 \mathrm{~kg}$ & 7,000 & 700,000 & 700,000 \\
\hline 2 & $\begin{array}{l}\text { Biaya Tenaga Kerja Langsung : } \\
\text { * Proses Produksi } \\
\text { * Biaya makan }\end{array}$ & $\begin{array}{l}50 \text { cetak } \\
2 \text { orang }\end{array}$ & $\begin{array}{l}2,500 \\
5,000 \\
\end{array}$ & $\begin{array}{l}125,000 \\
10,000\end{array}$ & \\
\hline & $\begin{array}{l}\text { * Biaya Rokok } \\
\text { Jumlah Biaya Tenaga kerja Langsung }\end{array}$ & 2 orang & 18,000 & 36,000 & 171,000 \\
\hline 3 & $\begin{array}{l}\text { Biaya Overhead Pabrik (BOP): } \\
\text { * Biaya Bahan Bakar } \\
\text { * Biaya Listrik } \\
\text { * Biaya air }\end{array}$ & $\begin{array}{l}10 \mathrm{krg} \\
1 \text { hari } \\
1 \text { hari }\end{array}$ & $\begin{array}{l}10,000 \\
2,000 \\
4,000 \\
\end{array}$ & $\begin{array}{l}100,000 \\
2,000 \\
4.000 \\
\end{array}$ & \\
\hline & * Biaya Bahan penolong (garam) & 1 hari & 2,000 & 2,000 & \\
\hline & $\begin{array}{l}\text { * By Bhn Penolong (air garam/air cuka) } \\
\text { * Biaya Penyusutan peralatan }\end{array}$ & 1 hari & $\begin{array}{l}20,000 \\
3,607 \\
\end{array}$ & $\begin{array}{l}20,000 \\
3,607\end{array}$ & \\
\hline & Jumlah Biaya Overhead Pabrik (BOP) & & & & 131,607 \\
\hline & $\begin{array}{l}\text { TOTAL } \\
\text { HARGA POKOK PRODUKSI } \\
\text { HPP / Cetak }\end{array}$ & \multicolumn{4}{|c|}{$\begin{array}{l}1,002,607 \\
\text { Rp. } 1.002 .607 / 50 \text { cetak }=\text { Rp. } 20.052\end{array}$} \\
\hline
\end{tabular}

Sumber: Data Primer (diolah) 


\section{Jurnal ABDIMAS INDEPENDEN}

Vol. 1, No. 1, Mei 2020

Berdasarkan perhitungan Harga Pokok Produksi dengan pendekatan Full Costing tersebut, maka keuntungan Bapak Satriawan percetak sebesar Rp. 9.948 (Rp.30.000 - Rp. 20.052), dan total keuntungan per hari $=$ Rp. $9.948 \times 50$ cetak $=$ Rp.497.400

\section{Pembahasan}

Kegiatan Pengabdian Pada Masyarakat ini dilakukan untuk mengetahui perhitungan Harga Pokok Produksi pada usaha Tahu Tempe milik Bapak Satriawan yang sudah dijalankan sekitar 32 Tahun lamanya, namun selama ini Bapak Satriawan tidak menggunakan metode apapun dalam perhitungan harga pokok produksinya. Setelah mengetahui perhitungan harga pokok produksi menurut yang dilakukan selama ini oleh Bapak Satriawan, selanjutnya akan dilakukan perhitungan harga pokok produksi menurut metode yang semestinya yaitu metode Full Costing.

Perhitungan harga pokok produksi tersebut difokuskan pada produk Tahu, mengingat produk Tempe sudah tidak dibuat sejak Tahun 2013. Oleh karena itu Bapak Satriawan bersedia memberikan data biaya produksi pembuatan Tahu. Dan berdasarkan informasi yang disampaikan oleh Bapak Satriawan mengenai harga pokok produksinya terdapat perbedaan dengan harga pokok produksi yang coba dihitung oleh tim Pengabdian berdasarkan data yang dikumpulkan.

Perhitungan harga pokok produksi pembuatan "Tahu" menurut Bapak Satriawan seperti yang terlihat pada Tabel 5, maka harga pokok produksi pembuatan Tahu per cetak sebesar Rp. 20.390. dengan nilai penjualan Rp. 30.000 percetak, maka keuntungan per cetak menurut perhitungan Bapak Satriawan sebesar Rp 9.610 (Rp.30.000 - Rp. 20.390). berbeda dengan perhitungan harga pokok produksi yang diperlihatkan pada Tabel 5, bahwa harga pokok produksi dengan menggunakan metode Full Costing sebesar Rp 20.052 per cetaknya. Sehingga dengan nilai penjualan Rp 30.000 per cetak, maka 
keuntungannya sebesar Rp 9.948 (Rp 30.000 - Rp 20.052) per cetaknya. Terdapat selisih harga pokok menurut perhitungan Bapak Satriawan dengan perhitungan Metode Full Costing sebesar Rp. 338 (Rp.20.390 - Rp.20.052) percetak dan Rp.16.900 (Rp.338 x 50 cetak) per hari.

\section{KESIMPULAN DAN SARAN}

\section{Kesimpulan}

Kegiatan Pengabdian ini berjalan dengan lancar dan telah berhasil memberikan pemahaman kepada Bapak Satriawan bahwa perhitungan harga pokok produksi yang diterapkan selama ini masih keliru, karena perhitungannya tidak berdasar pada metode atau konsep Full Costing atau Variabel Costing. Kegiatan pengabdian terlaksana pada hari Kamis, 8 Agustus 2019 yang dimulai dari Pukul 09.00 wita sampai dengan selesai. Kegiatan pengabdian dilaksanakan dengan menggunakan metode diskusi dua arah antara Bapak Satriawan dengan tim pengabdian. Dari kegiatan pengabdian ini memberikan kesimpulan bahwa terdapat selisih harga pokok menurut perhitungan Bapak Satriawan dengan perhitungan Metode Full Costing sebesar Rp. 338 (Rp.20.390 - Rp.20.052) percetak dan Rp.16.900 (Rp.338 x 50 cetak) per hari.

\section{Saran}

Berdasarkan temuan / hasil dari kegiatan pengabdian yang menunjukkan bahwa Bapak Satriawan masih keliru di dalam menghitung harga pokok produksinya, sehingga terdapat perbedaan besaran harga pokok produksi menurut perhitungan Bapak Satriawan dengan perhitungan harga pokok produksi yang didasarkan pada metode Full Costing. Maka disarankan Bapak Satriawan menerapkan perhitungan Harga Pokok Produksi dengan pendekatan Full Costing, supaya bisa mengetahui keuntungan sebenarnya. Dikarenakan perhitungan menurut Bapak Satriawan terlalu besar membebankan beberapa biaya overhead pabrik ke produk, terutama biaya yang sifatnya tetap. 
Jurnal ABDIMAS INDEPENDEN

Vol. 1, No. 1, Mei 2020

\section{DAFTAR PUSTAKA}

Aripin, Zainal. 2014. Analisis Harga Pokok Produksi Tahu Tempe Pada Home Industri Lela Jaya Manna, Bengkulu Selatan.Skripsi. Jurusan Manajemen. FEB Universitas Bengkulu.

Mulyadi. (1997). Akuntansi Manajemen. Yogyakarta: STIE YKPN.

Mulyadi. (2012). Akuntansi Biaya. Yogyakarta: BPFE.

Suprihatin, Latib. 2009. Penyusunan Harga Pokok Produksi Pada Pabrik Tahu “ Bu Gito" Pedan Dengan Metode Process Costing. Tugas Akhir. Prodi D3 Akuntansi. FEB Universitas Sebelas Maret Surakarta.

Supriyono. (1999). Akuntansi Biaya. Yogyakarta: BPFE. 